\title{
DIFFERENTIATION OF THE OLFACTORY EPITHELIUM IN SWINE IN ONTOGENESIS
}

\author{
S. HOLUBCOVÁ, I. KOCIÁNOVÁ, F.TICHÝ \\ Department of Anatomy, Histology and Embryology, \\ Faculty of Veterinary Medicine, \\ University of Veterinary and Pharmaceutical Sciences, Brno
}

Received April 18, 1997

Accepted November 4, 1997

\begin{abstract}
Holubcová S., I. Kociánová, F. Ti chý: Differentiation of the Olfactory Epithelium in Swine in Ontogenesis. Acta vet. Brno, 1997, 66:135-139.

The structure of the olfactory epithelium was studied in swine by means of light microscopy along with its morphology and the development of the olfactory epithelium.

The material for light microscopical methods was obtained from the mucosa of the fetal regio olfactoria of piglets on day $41,55,57,60,64$ and 94 of gestation and 5 days after the birth.

The structure of the olfactory epithelium consists of supporting cells, olfactory neurons and basal cells which appear in early developmental stages (on 41 day of gestation). During the prenatal development the number of individual cells continued to increase and the olfactory epithelium with thickness of about $30 \mu \mathrm{m}$ in 41 -day-old foetuses reached a thickness of about $120 \mu \mathrm{m}$ in 5-day-old piglets. The fibrous structures on the surface of the epithelium were visible in 41 -day-old foetuses and apical parts of supporting and sensory cells formed light strip in 55-day-old foetuses. The discontinuous development of individual cells was especially remarkable in 64-day-old foetuses. In lamina propria mucosae the bands of axons and olfactory glands and their development in 94day-old foetuses were clearly visible.
\end{abstract}

Light microscopy, sense organs, development, olfactory mucosa

The olfactory epithelium covers the caudodorsal portion of the nasal cavity including some areas of the ethmoid conchae, dorsal nasal meatus, and nasal septum. This sensory epithelium plays an important role in the detection and processing of chemical odorants in the inspired air.

Many authors have been engaged in studies of the microscopic structure of the olfactory epithelium in various animal species. This epithelium was described in fish and amphibians (Usukura and Yamada 1978; Menco and Farbman 1992; Moran et al. 1992), in reptiles (Matsuzaki et al. 1980; Wang et al. 1980), in birds (B ang 1971; Matsuzaki 1995), in various mammals (Graziadei 1971; Loo 1977; Hinds et al. 1984; Constanzo and Morrison 1989; Naguro and Iwashita 1992) and especially in man (Nakashima et al. 1984; Chuah and Zheng 1992; Morrison and Constanzo 1990, 1992; Morrison and Moran 1994). Some studies have been devoted to the morphology of the olfactory epithelium in domesticated animals such as in cattle and sheep (Kratzing 1970; Menco 1977; Menco et al. 1978), rabbits (Yamamoto 1976), dogs (Okano et al. 1967) and swine (A gas a ndy an 1990).

All these studies show that the structure of the olfactory epithelium is similar in vertebrate species studied so far. In this epithelium three types of cells have been identified: supporting, sensory and basal. These types of cells form three zones of the olfactory epithelium: the upper zone with nuclei of supporting cells, the middle zone with nuclei of receptor cells and the lower zone with nuclei of basal cells ( $\mathrm{Grazi}$ a de i 1971; Morris on and Con stanzo 1990). Recently, a fourth type of epithelial cells was described: microvillar cell (Agas and y an 1990; Moris s on and Moran 1994). 
The purpose of this study was to obtain detailed information on the swine olfactory epithelium and to provide a base for further comparative and functional studies.

\section{Materials and Methods}

Olfactory tissue was obtained at autopsy from the mucosa of porcine foetuses aged 41. 55, 57,60.64 and 94 days. In order to obtain a complete picture and specimens were also taken from piglets aged 5 days. Three animals of each age were used.

The age of the foetuses was determined according to Ev ans and S ack (1973) and was based on the distance between the vertex and tail root.

The skull of foetuses was opened by sagittal section and after removing the septum nasi a piece of the mucosa of 3rd endoturbinate was taken. The block of tissue was immediately placed in a fixative (10\% formaldehyde), for $1-2$ days, then rinsed, dehydrated in graded alcohols, and transferred and embedded in paraffin. The sections were routinely stained with hematoxylin and eosine (HE). To intensify the visualization of selected structures, the impregnation technique by Gomori and nuclear red staining were used. Some of the sections were stained with the green trichrome reasent.

\section{Results}

\section{Porcine foetuses aged 41 days}

The epithelium of the regio olfactoria nasi of this age group was not very high yet, its height reached $30 \mu \mathrm{m}$. This low pseudostratified columnar epithelium consisted of several cell types that could be distinguished by the position of their nuclei (Plate I, Fig. 1). In the basal part of the epithelium we found a continuous layer of round dark nuclei of basal cells. In the upper part of the epithelium we recognized large, oval nuclei of supporting cells. On the olfactory epithelial surface fibrous structures were visible.

Lamina propria of the epithelium, formed by connective tissue, contained small blood vessels. Bowman's glands have not been formed yet and also axon fascicles were not visible.

\section{Porcine foetuses aged 55 days}

In the pseudostratified columnar epithelium of porcine foetuses aged 55 days (height about $60 \mu \mathrm{m}$ ) three cells three types were found. In addition to the continuous line of dark, round nuclei of basal cells the middle layer of light, round nuclei of receptor cells were detected (Plate I, Fig. 2). Supporting cells were distinguished from receptor cells by their oval and elongated nuclei and by localization of their nuclei in the upper epithelium. In connection with cytoplasm growth of supporting cells a light strip formed by their apical parts was developing. Due to a higher number of cells the epithelium increased its height.

The olfactory epithelium resided on a highly cellular lamina propria mucosae that contained few blood vessels and small axon fascicles of olfactory receptor cells. Bowman's glands were not yet visible.

\section{Porcine foetuses aged 57 days}

The $90 \mu \mathrm{m}$ high olfactory epithelium, had a relatively smooth surface without any fibrous structures. We distinguished a dark line and a light strip below it in the upper part of the epithelium (Plate II, Fig. 3). Basal cells, supporting cells and receptor cells had their characteristic arrangement and features. In this age category the nuclei of receptor cells were clear. Basal cells in the lower part of the epithelium adjacent to the basal lamina were found occasionally. Moreover, light secretory cells occurred in the olfactory epithelium.

Lamina propria mucosae contained numerous blood lacunae and axon fascicles - fila olfactoria, but no Bowman's glands.

Porcine foetuses aged 60 days

The height of the olfactory epithelium was the same as in the previous stage. The dividing 
line between the olfactory and the respiratory regions of the nasal mucosa was sharply indicated (Plate II, Fig. 4). The dark line and light strip below it were recognized as in the preceding stage of development. Nuclei of supporting cells occurred like a dark zone in the upper epithelium. Basal cells were generally located in the basal epithelial region and formed discontinuous layer.

In the highly cellular lamina propria mucosae blood vessels were present. Bowman's glands were not yet formed.

\section{Porcine foetuses aged 64 days}

The olfactory epithelium $(90 \mu \mathrm{m})$ of this age category formed a very irregular surface with many prominences (Plate III, Fig. 5). Above the dark line various fibrous formations were visible. Light spherical nuclei of receptor cells were well distinguished from oval nuclei of supporting cells in the upper zone of the epithelium.

In the loose connective tissue of lamina propria mucosae numerous blood lacunae and bands of nervous fibers and still no Bowman's glands were found.

\section{Porcine foetuses aged 94 days}

On the surface of the olfactory epithelium, which was now $110 \mu \mathrm{m}$ high, we could find fine fibrous structures which projected from the apical part of epithelial cells (Plate III, Fig. 6 ). In the upper zone of the epithelium we observed nuclei of supporting cells just below the dark line.

Lamina propria mucosae contained developing tubuli and ducts of glandulae olfactoriae.

\section{Piglets aged 5 days}

The olfactory epithelium of piglets aged 5 days was high (about $120 \mu \mathrm{m}$ ) and well developed. Three types of cells were observed and distinguished by their nuclei form and localization in the epithelium (Plate IV, Fig. 7). The number of cells grew up especially in the middle zone of the olfactory epithelium. Above the dark line on the epithelium surface the continuous layer of fine fibrous structures were visible. Below this dark line apical parts of supporting cells formed the light band with an almost uniform width. Dark, oval nuclei of supporting cells were concentrated in the continuous dark layer. In the middle part of the epithelium round, light receptor cells nuclei were situated forming 8-10 rows.

The dividing line between the regio olfactoria and regio respiratoria was clearly indicated by different features of the both epithelium.

In lamina propria mucosae we found well developed fila olfactoria and Bowman's glands.

\section{Discussion}

Our studies have demonstrated that the porcine olfactory neuroepithelium had a structure similar to that found in other vertebrates being pseudostratified columnar and composed of olfactory receptor cells, nonsensory supporting cells, and basal cells. These types of cells formed three zones of the olfactory epithelium.

Individual cell types of the olfactory epithelium can be distinguished by the position of their nuclei from $\mathrm{d} 41$ of the prenatal period. A continuous layer of round dark nuclei of basal cells can already be seen at the base of the epithelium from this age. Basal cells are generally considered to be the initial elements for the development of individual cell types of the olfactory epithelium (Graziadei and Monti Graziadei 1979; Moran et al. 1982).

The developing sensory cells can be recognized by their lighter spherical nuclei which are particularly apparent in the middle zone of the neuroepithelium (Morris on and Moran 
1994). The nuclei of sensory cells can be well distinguished from those of supporting cells from $\mathrm{d} 55$. The number of sensory cells is increased with increasing age and consequently the neuroepithelium, which has a thickness of about 3-4 rows of cells in 41-day-old foetus, reaches a thickness of about 8-10 rows of cells in 5-day-old piglets.

Supporting cells are typical with their oval and elongated nuclei found in the upper epithelium (Yamada 1983; Constanzo and Morrison 1989). Their characteristic arrangement and features were observed from d 55 .

Some authors (A gasandyan 1990; Morisson and Moran 1994) described a fourth cell type of, which is, however, not distinguishable by light microscopy.

The continuity of the line of basal cells is impaired only around d 64, apparently in connection with the beginning of the formation of ducts of glandulae olfactoriae.

All developmental stages presented here showed a marked dark line on the surface of the epithelium, that is probably formed by the developing olfactory endings and developing microvilli of supporting cells ( Ti c hy et al. 1995). The development of apical parts of the supporting and sensory cells of the neuroepithelium could be seen around $\mathrm{d} 60$. The apical parts elongated and were visible as a marked light strip below the surface line. At the same time the differentiation of the surface of the olfactory epithelium in form of fine filamentous structures and small protuberances became apparent. Their numbers grew with advancing age of the fetus (Morris on and Constanzo 1990; Tichý et al. 1995).

The olfactory epithelium resides on a highly cellular lamina propria mucosae, that contains axons fascicles, blood vessels, connective tissue, and Bowman's glands (Graziade i 1971; M orris on and M or an 1994). Olfactory axons arise from the basal region of the receptor cell body, pass through the basal lamina, and form larger axon fascicles - fila olfactoria (Morris on and Constanzo 1990; Morris on and Moran 1994). The finding of fine nervous filaments in the primitive connective tissue of lamina propria mucosae was evident from d 41 and documented the existence of differentiating sensory cells. We observed that the number of the nervous filaments increased during the intrauterine development forming larger axon fascicles. Apparently it is a result of the increase in the number of olfactory receptors in the neuroepithelium.

\section{Diferenciace čichového epitelu u prasete v ontogenezi}

Byla studována stavba čichového epitelu u prasete za použití světelné mikroskopie. Zkoumali jsme nejen morfologii ale i vývoj čichového epitelu.

Materiál pro studium ve světelném mikroskopu byl získán ze sliznice čichové oblasti fetů prasete ve stáři $41,55,57,60,64$ a 94 dnů březosti a 5 dnů po narození.

Čichový epitel je tvořen podpůrnými buňkami, čichovými neurony a bazálními buňkami, které rozlišíme už v raných vývojových stadích (od 41. dne gestace). Během prenatálního vývoje počet jednotlivých buněk roste a čichový epitel o výšce $30 \mu \mathrm{m}$ u 41 dnů starého fetu dosahuje výšky kolem $120 \mu \mathrm{m}$ u 5denního selete. Už u fetu 41 dnů starého jsou patrné vláknité struktury na povrchu epitelu a u 55 dnů starého fetu tvoři apikální části podpůrných a smyslových buněk světlý proužek. Nerovnoměrný vývoj jednotlivých buněk je obzvláště patrný u 64 dnů starého fetu. Svazky axonů a čichové žlázy jsou zřetelně rozvinuty u 94 dnů starého fetu.

\section{Acknowledgements}

The study was supported by an internal grant of the University of Veterinary and Pharmaceutical Sciences in Brno. 


\section{References}

AGASANDYAN. KH.V. 1990: Microvillar cells in swine olfactory epithelium. J. Evol. Biochem. Physiol. 26: 194198

BANG. B.G. 1971: Functional anatomy of the olfactory system in 23 orders of birds. Acta Anat. Suppl. 79: 1-76

CHUAH. M.I., ZHENG. D.R. 1992: The human primary olfactory pathway: fine structural and cytochemical aspects during development and in adults. Microsc. Res. Tech. 23: 76-85

CONSTANZO, R.M., MORRISON, E.E. 1989: Three-dimensional scanning electron microscopic study of the normal hamster olfactory epithelium. J. Neurocytol. 18: 381-391

EVANS, H.E., SACK, W.O. 1973: Prenatal development of domestic laboratory mammals. Growth curves, external features and selected references. Anat. Histol. Embryol. 2: 11-45

GRAZIADEI MONTI. G.A., GRAZIADEI, P.P.C. 1979: Neurogenesis and neuron regeneration in the olfactory system of mammals. II. Degeneration and reconstitution of the olfactory sensory neurons after axotomy. J. Neurocytol. 8: 197-213

GRAZIADEI, P.P.C. 1971: The ultrastructure of vertebrate olfactory mucosa. In: Ultrastructure of animal tissue and organs. I.Friedman, ed. North-Holland, Amsterdam, pp. 269-305.

HINDS, J.W.. HINDS. P.L., MC NELLY. N.A. 1984: An autoradiographic study of the mouse olfactory epithelium: evidence for long-lived receptors. Anat. Rec. 210: 375-383

KRATZING. J.E. 1970: The olfactory mucosa of the sheep. Aust.J.Biol.Sci. 23: 447-458

LOO, S.K.1977: Fine structure of the olfactory epithelium in some primates. J. Anat. 123: 135-145

MATSUZAKI. O.. SHIBUYA. T., HATANAKA.T. 1980: The number of olfactory receptor cells in the four-toed tortoise. Testudo horsfieldi. Zool. Mag. 89: 192-195

MATSUZAKI, O. 1995: Numbers of olfactory receptor cells and fine structure of olfactory nerves in various birds. Zool. Science. 12: 117-123

MENCO. B.PH.M. 1977: A qualitative and quantitative investigation of olfactory and nasal respiratory mucosal surfaces of cow and sheep based on various ultrastructural and biochemical techniques. Communications Agricultural University, Wageningen. 77-13, pp.1-157.

MENCO. B.PH.M.. LEUNISSEN, J.L.M., BANNISTER. L.M., DODD. G.H. 1978: Bovine olfactory and nasal respiratory epithelium surfaces. High voltage and scanning electron microscopy, and cryo-ultramicrotomy. Cell Tissue Res. 193: 503-524

MENCO, B.PH.M.. FARBMAN, A.I. 1992: Ultrastructural evidence for multiple mucous domains in frog olfactory epithelium. Cell Tissue Res. 270: 47-56

MORAN. D.T., ROWLEY, J.C.III., JAFEK, B.W. 1982: Electron microscopy of human olfactory epithelium reveals a new cell type: the microvillar cell. Brain Res. 253: 39-46

MORAN. D.T., ROWLEY. J.C.III., AIKEN, G.R., JAFEK. B.W. 1992: Ultrastructural neurobiology of the olfactory mucosa of the brown trout. Salmo trutta. Microsc. Res. Tech. 23: 28-48

MORRISON. E.E., CONST ANZO. R.M. 1990: Morphology of the human olfactory epithelium. J. Compar. Neur. 297: $1-13$

MORRISON. E.E., MORAN. D.T. 1994: Anatomy and ultrastructure of the human olfactory neuroepithelium. In: Handbook of olfaction and gustation. R.L.Doty, ed. Philadelphia. Pennsylvania. pp.75-101.

MORRISON, E.E.. CONSTANZO, R.M. 1992: Morphology of olfactory epithelium in humans and other vertebrates. Microsc. Res. Tech. 23: 49-61

NAGURO. T., IWASHITA, K. 1992: Olfactory epithelium in young adult and aging rats as seen with highresolution scanning electron microscopy. Microsc. Res. Tech. 23: 62-75

NAKASHIMA. T., KIMMELMAN. C.P., SNOW. J.B. 1984: Structure of human fetal and adult olfactory neuroepithelium. Arch. Otolaryngol. 110: 641-646

OKANO, M., WEBER. A.F., FROMMES. S.P. 1967: Electron microscopic studies of the distal border of the canine olfactory epithelium. J. Ultrastruct. Res. 17: :487-502

TICHYY. F.. HORKY. D.. MIŠEK. I. 1995: Differentiation of the olfactory epithelium in sheep in ontogenesis using scanning electron microscopy. Acta vet. Brno 64: $71-77$

USUKURA. J.. YAMADA. E. 1978: Observation on the cytolemma of the olfactory receptor cell in the newt. Freeze replica analysis. Cell Tiss. Res. 188: $83-98$

WANG. R.T., HALPERN, M. 1980: Light and electron microscopic observations on the normal structure of the vomeronasal organ of garter snakes. J. Morphol. 164: 47-67

YAMADA. S. 1983: Scanning electron microscopic study of olfactory epithelia. J. Clin. Elect. Microsc. 16: 95-108

YAMAMOTO. M. 1976: An electron microscopic study of the olfactory mucosa in the bat and rabbit. Arch. Histol. Japonicum 38: $359-412$

Address for correspondence:

MVDr. Simona Holubcová

Department of Anatomy. Histology and Embryology

Faculty of Veterinary Medicine

University of Veterinary and Pharmaceutical Sciences

Palackého 1-3

61242 Brno

Czech Republic

Phone: ++20 541562207 


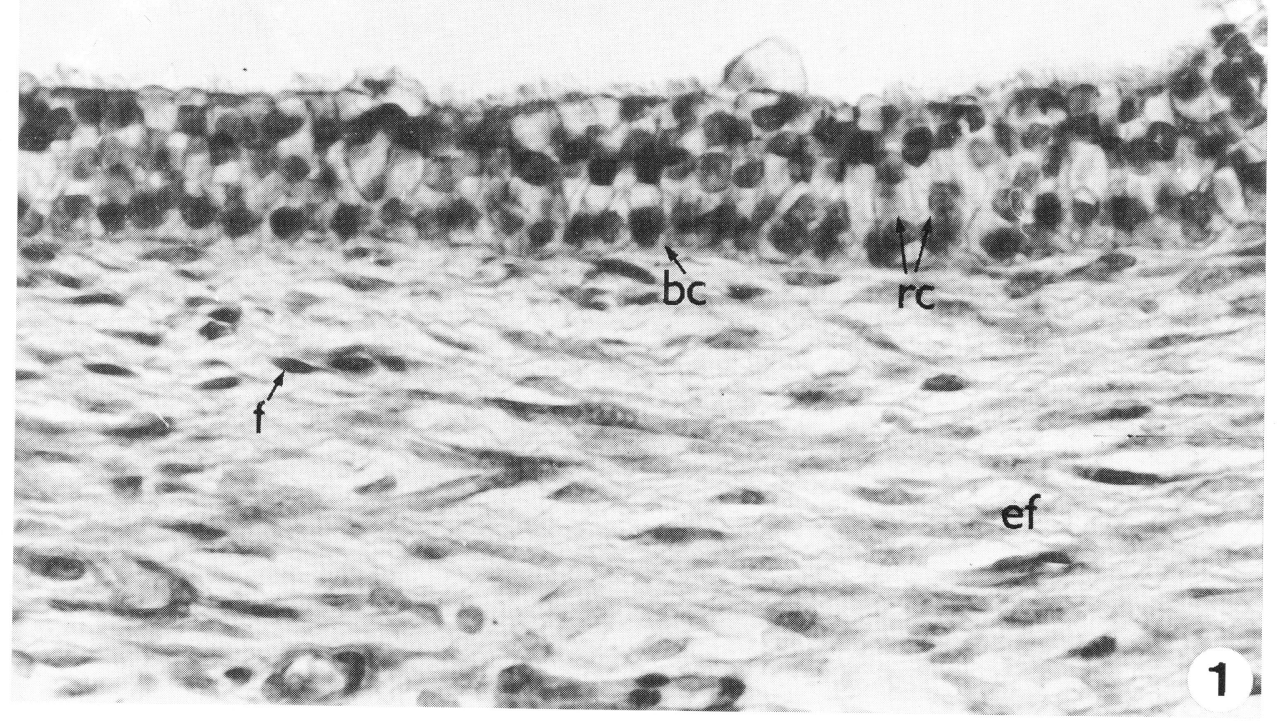

Fig. 1: Regio olfactoria of a 41-day-old porcine foetus. Nuclei of basal cells (bc), light receptor cells (rc). Lamina propria mucosae consisting of loose connective tissue with nuclei of fibroblasts (f) and elastic fibers (ef).
$\mathrm{HE}, \times 600$

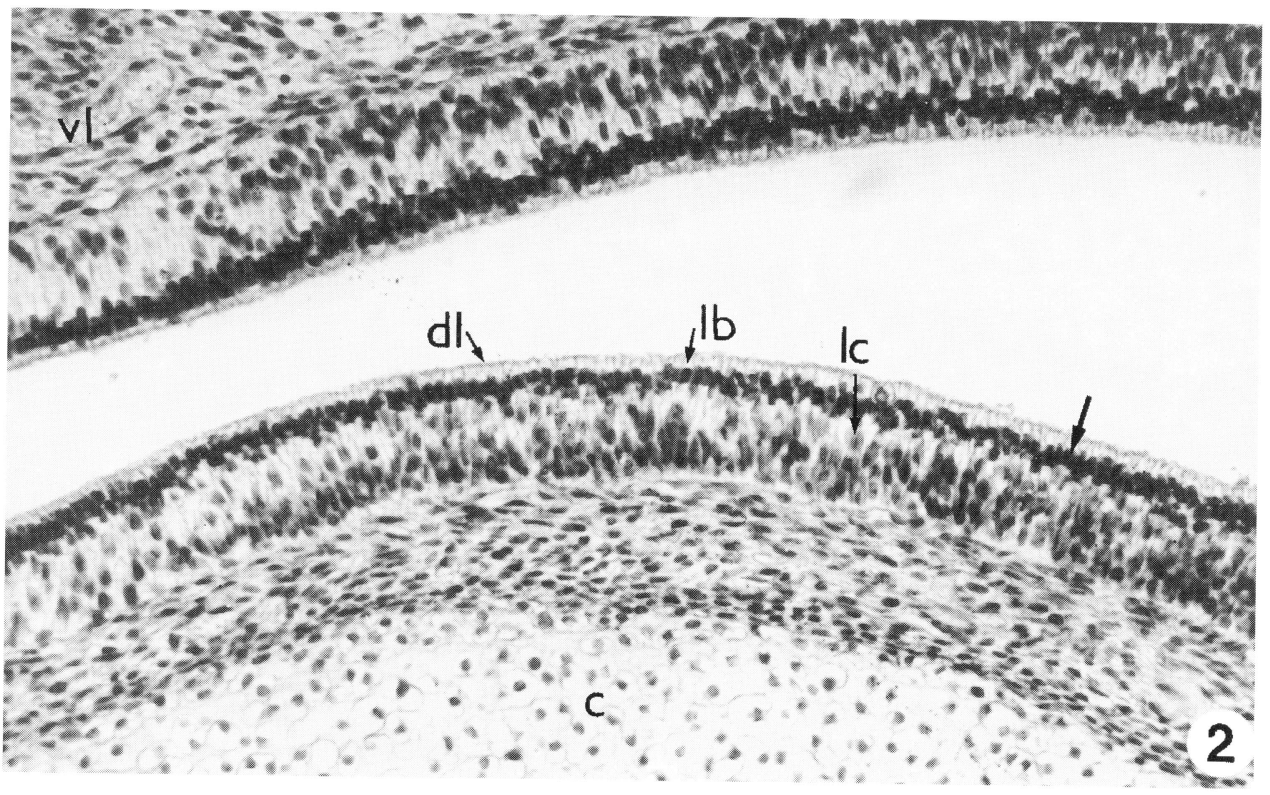

Fig. 2. Olfactory epithelium of a 55-day-old foetus. Dark line (dl), Light band (lb), nuclei of sustentacular cells $(-->)$, nuclei of receptor cells (lc). Venous lacunae (vl) in lamina propria mucosae. Cartilage (c). HE, $\times 400$ 
Plate II.

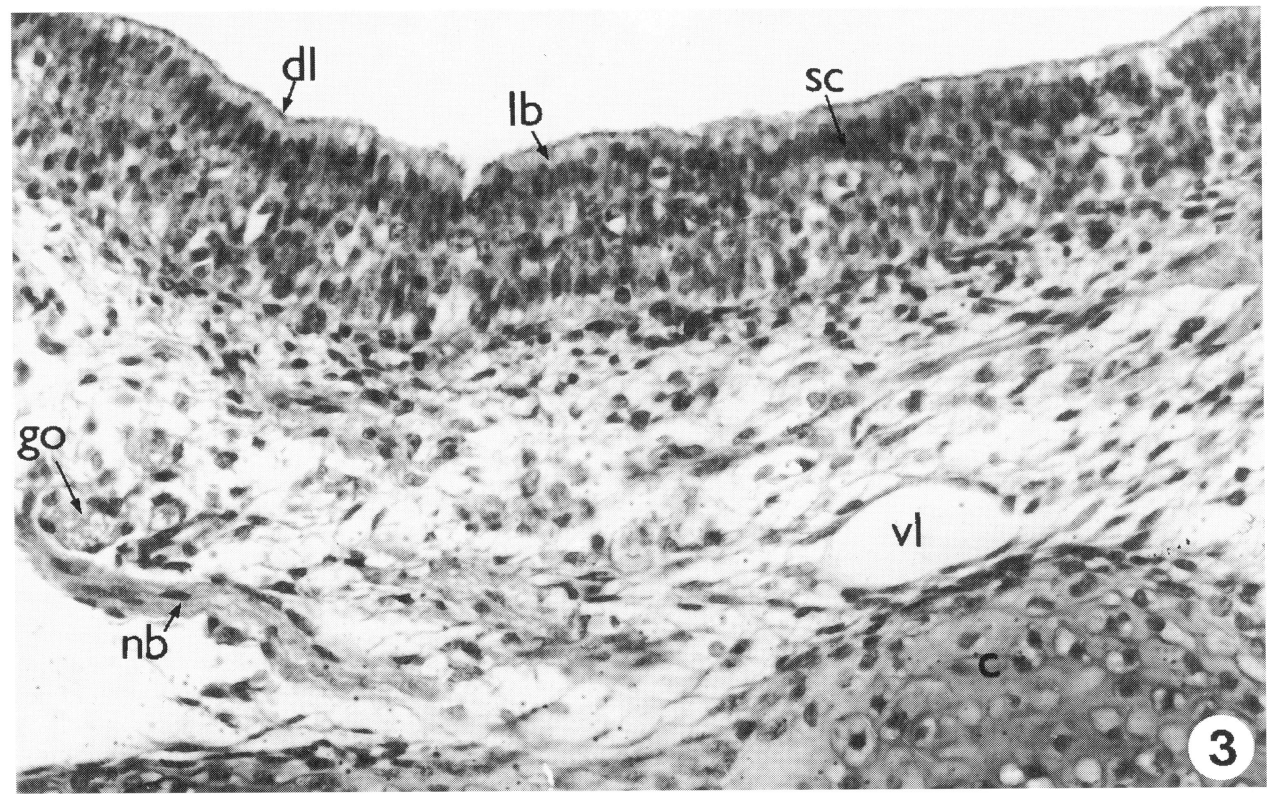

Fig. 3. The olfactory mucosa of a 57-day-old porcine foetus. Dark line (dl), light band (lb) below it consisting of apical parts of sustentacular cells, stratum of nuclei of sustentacular cells (sc). Developing tubulus of glandulae olfactoriae (go), nervous band (nb) and venous lacunae (vl) in lamina propria mucosae. Cartilage (c). $\mathrm{HE}, \times 400$

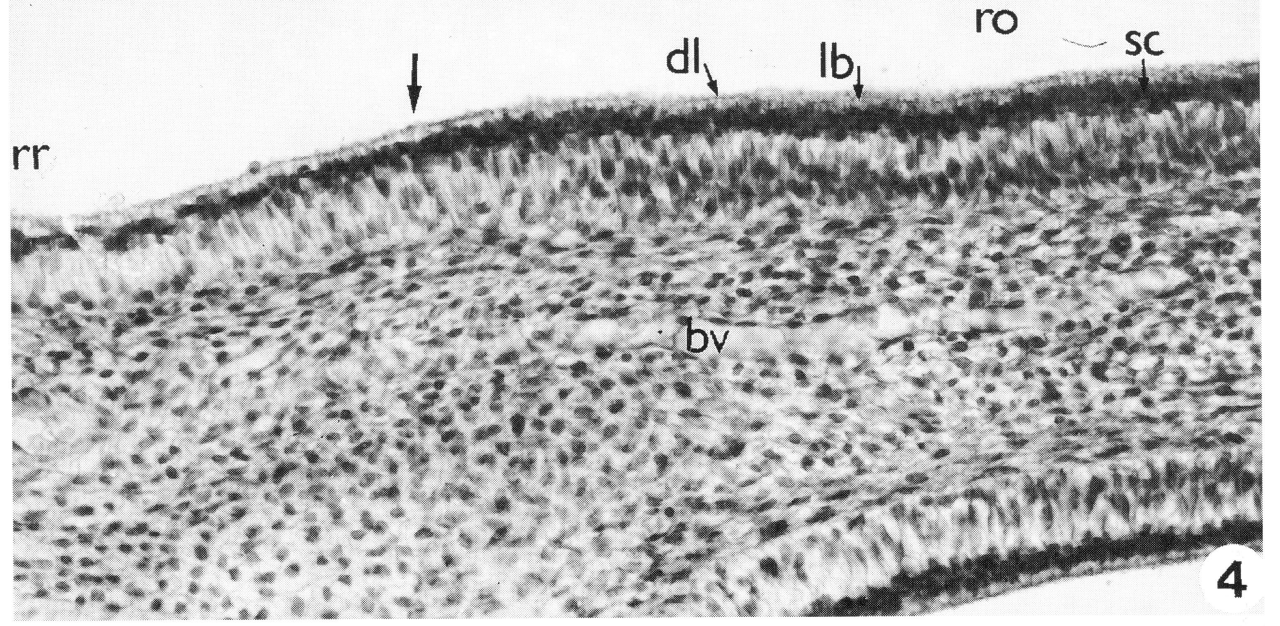

Fig. 4. Part of nasal meatus of a 60-day-old porcine foetus. The dividing line $(->)$ between the regio respiratoria (rr) and regio olfactoria (ro). Nuclei of sustentacular cells (sc), light band (lb) formed by apical parts of these cells. Above it dark line (dl) is visible. Blood vessel (bv) in lamina propria mucosae. HE, $\times 400$ 


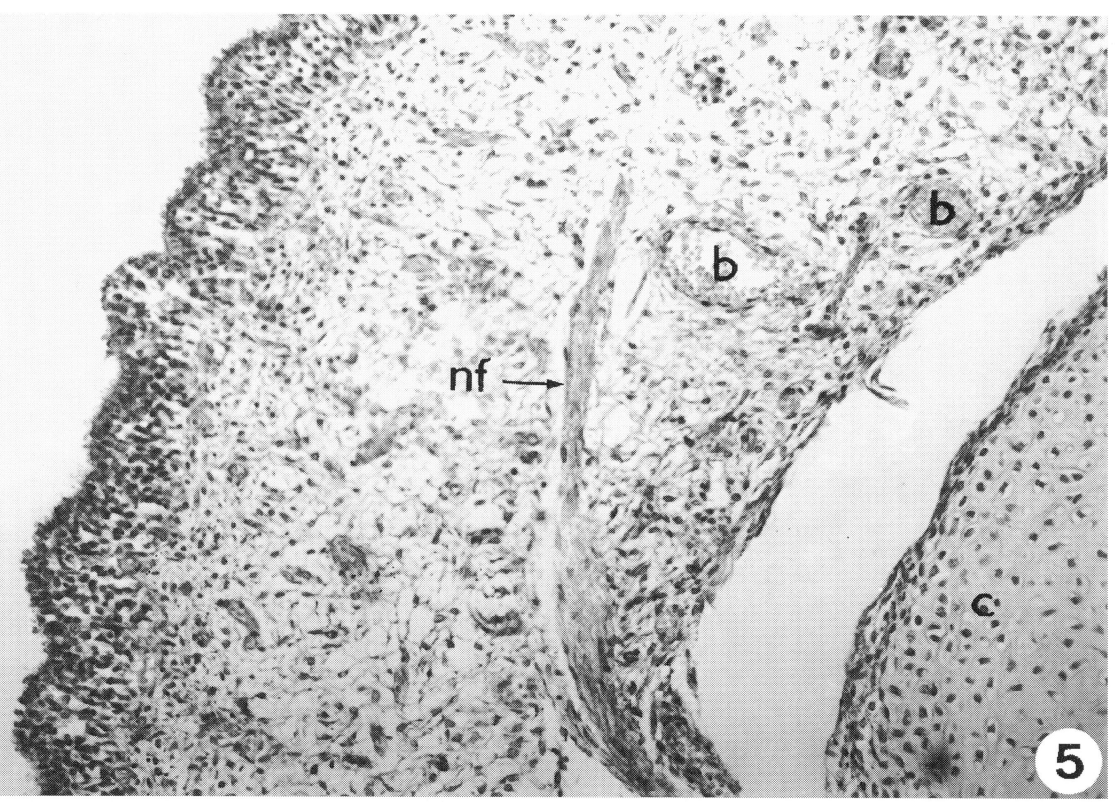

Fig. 5. Regio olfactoria of a 64-day-old porcine foetus. Lumina of blood lacunae (b) and bands of nervous fibers (nf) in loose connective tissue. Cartilage (c). HE, $\times 250$

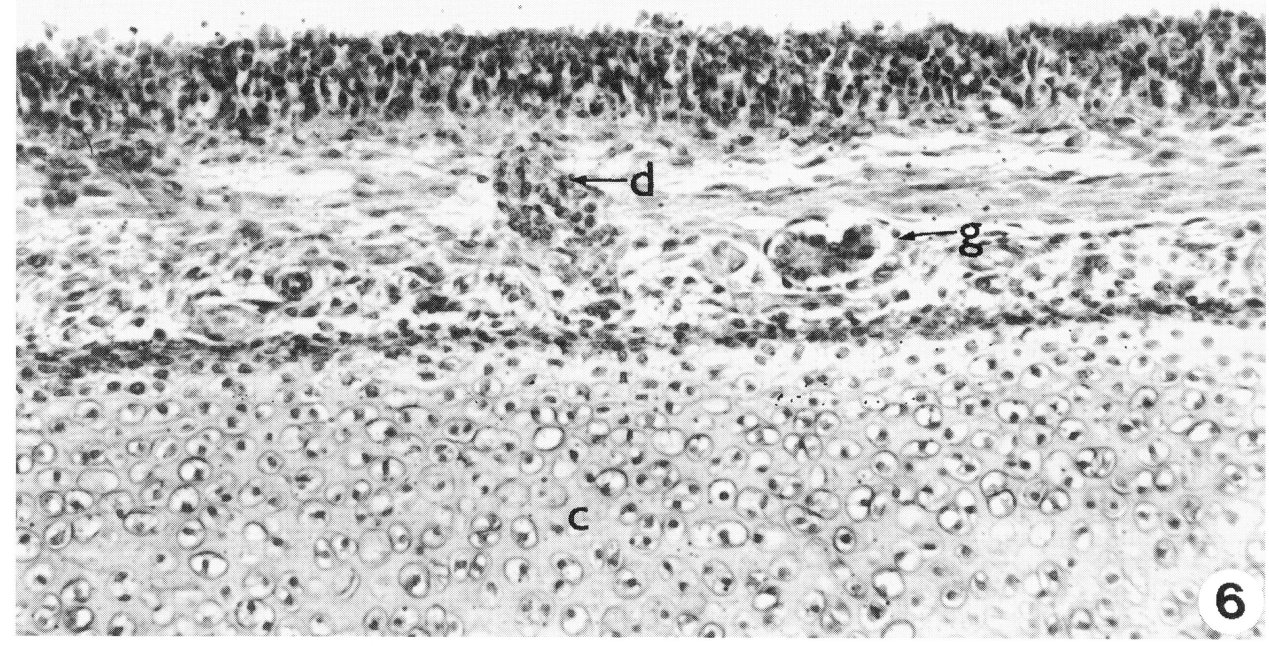

Fig. 6. The olfactory mucosa of a 94-day-old porcine foetus. Gland tubulus (g) and developing duct (d) of glandulae olfactoriae in lamina propria mucosae. Cartilage (c). HE, $\times 250$ 


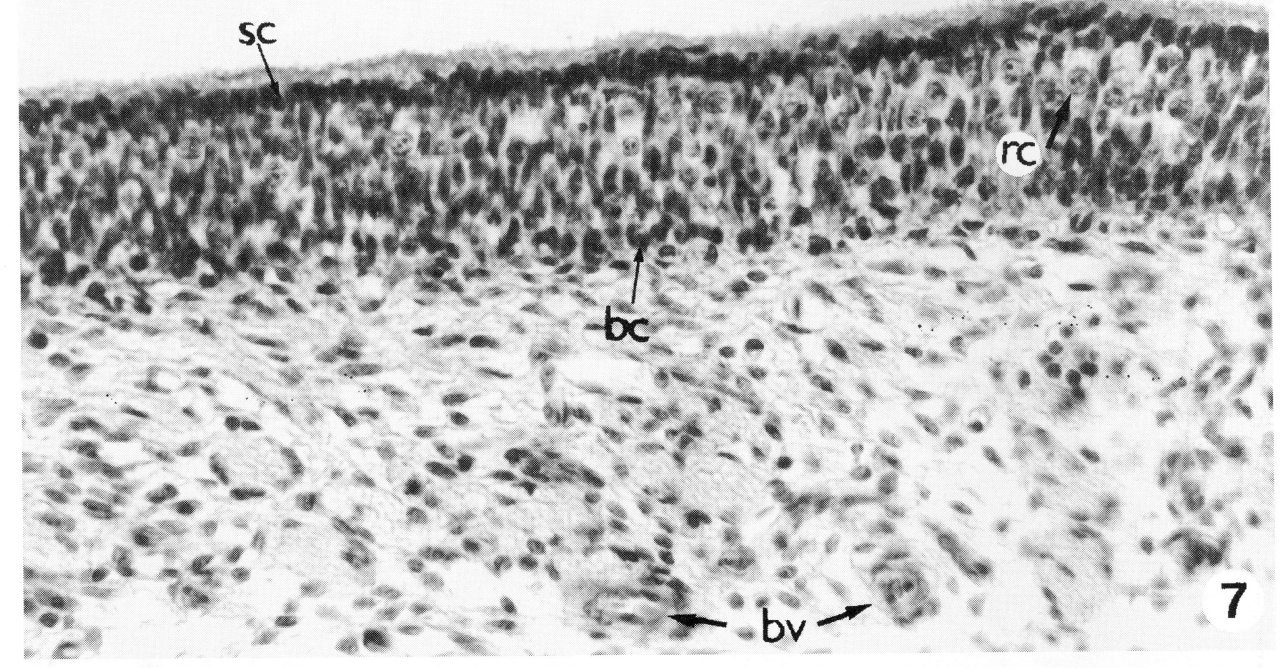

Fig. 7 Regio olfactoria of a 5-day-old piglet. Nucleus of sustentacular cell (sc), nucleus of basal cell (bc), light nucleus of receptor cell (rc). Blood vessels (bv). HE, $\times 400$ 